\title{
MEASUREMENT AND SIMULATION OF SOLAR RADIATION AVAILABILITY IN RELATION TO THE GROWTH OF COFFEE PLANTS IN AN AGROFORESTRY SYSTEM WITH RUBBER TREES ${ }^{1}$
}

\author{
Ciro Abbud Righi ${ }^{2}$, Marcos Silveira Bernardes ${ }^{3}$, Aureny Maria Pereira Lunz ${ }^{4}$, Carlos Rodrigues Pereira ${ }^{5}$, \\ Durval Dourado Neto $^{3}$ e José Laercio Favarin ${ }^{3}$
}

\begin{abstract}
Solar radiation is an important factor for plant growth, being its availability to understory crops strongly modified by trees in an Agroforestry System (AFS). Coffee trees (Coffea arabica - cv. Obatã IAC 166920) were planted at a $3.4 \times 0.9 \mathrm{~m}$ spacing inside and aside rows of monocrops of 12 year-old rubber trees (Hevea

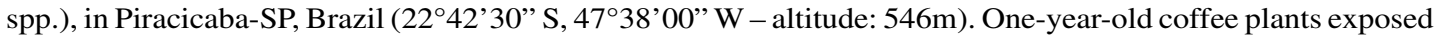
to $25 ; 30 ; 35 ; 40 ; 45 ; 80 ; 90 ; 95$ and $100 \%$ of the total solar radiation were evaluated according to its biophysical parameters of solar radiation interception and capture. The Goudriaan (1977) adapted by Bernardes et al. (1998) model for radiation attenuation fit well to the measured data. Coffee plants tolerate a decrease in solar radiation availability to $50 \%$ without undergoing a reduction on growth and LAI, which was approximately $2 \mathrm{~m}^{2} . \mathrm{m}^{-2}$ under this condition. Further reductions on the availability of solar radiation caused a reduction in LAI $\left(1.5 \mathrm{~m}^{2} . \mathrm{m}^{-2}\right)$, thus poor land cover and solar radiation interception, resulting in growth reduction.
\end{abstract}

Keywords: Solar radiation, attenuation, coffee, rubber tree and model.

\section{MEDIDAS E SIMULAÇÕES DA DISPONIBILIDADE DE RADIAÇÃO SOLAR RELACIONADAS AO CRESCIMENTO DE CAFEEIROS EM UM SISTEMA AGROFLORESTAL COM SERINGUEIRA}

\begin{abstract}
RESUMO - A radiação solar é um fator importante para o crescimento das plantas, sendo sua disponibilidade fortemente modificada pelas árvores em sistemas agroflorestais ( $S A F s$ ). Foram estudadas plantas de café (Coffea arabica - cv. Obatã IAC 1669-20) espaçadas 3,4 $\times$ 0,9 m em fileiras, dentro e ao lado de uma plantação

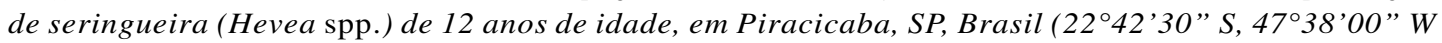
- altitude: $546 \mathrm{~m}$ ). Cafeeiros de 1 ano de idade expostos aos níveis de 25, 30, 35, 40, 45, 80, 90, 95 e $100 \%$ de radiação solar foram avaliados quanto aos seus parâmetros biofísicos de interceptação e captura de luz. O modelo de Goudriaan (1977) adaptado por Bernardes et al. (1998) para estimativa da radiação solar disponível ajustou-se bem aos dados medidos. Os cafeeiros toleraram diminuição de $50 \%$ na disponibilidade de radiação solar sem sofrer reduções no crescimento e IAF, sendo este de aproximadamente $2 \mathrm{~m}^{2} . \mathrm{m}^{-2}$, nessas condições. Reduções na disponibilidade de luz acima desse valor levaram a uma diminuição do IAF (1,5 $\left.\mathrm{m}^{2} . \mathrm{m}^{-2}\right)$, resultando em menor cobertura do solo pelos cafeeiros e menor interceptação da radiação solar, com conseqüentes diminuições no crescimento.
\end{abstract}

Palavras-chave: Radiação solar, atenuação, café, seringueira e modelo.

\footnotetext{
${ }^{1}$ Recebido em 06.06.2006 e aceito para publicação em 21.03.2007.

${ }^{2}$ Centro de Energia Nuclear na Agricultura - CENA. Universidade de São Paulo-USP. E-mail:<carighi@yahoo.com>.

${ }^{3}$ Escola Superior de Agricultura “Luiz de Queiroz”-ESALQ.E-mail:<msbernar@esalq.usp.br; dourado@esalq.usp.br;jlfavari@esalq.usp.br>.

${ }^{4}$ Empresa Brasileira de Pesquisa Agropecuária, Centro de Pesquisa Agroflorestal do Acre. E-mail<aureny @cpafac.embrapa.br>.

${ }^{5}$ Universidade Federal Rural do Rio de Janeiro, Instituto de Florestas. E-mail:<carlosrodriguespereira@ yahoo.com.br>.
} 


\section{INTRODUCTION}

Arabic coffee (Coffea arabica L.) originated in the high lands of Southern Ethiopia, close to the equator, at latitudes 6 to $9^{\circ} \mathrm{N}$, longitudes of 34 to $40^{\circ} \mathrm{E}$ and altitudes of 1400 and 1800 meters. This region has a dry season that lasts for 3 to 4 months, and the annual precipitation ranges from 1,200 to $2,000 \mathrm{~mm}$ throughout the year with temperature varying from 18 to $22^{\circ} \mathrm{C}$. In this area, coffee plants grow permanently under condition of shade in the tropical forest (KRUG, 1959; KUMAR, 1979).

Coffee is widely grown around the world (EVANOFF, 1994). In Latin America, there are commercial plantations extending from Cuba (latitude: $22^{\circ} \mathrm{N}$ ) to the State of Parana in Brazil (latitude: $26^{\circ} \mathrm{S}$ ). In Brazil, coffee is commercially cultivated under full sun condition. In countries such as Colombia, it is mostly shade-grown. Coffee cultivation as a monocrop may present problems such as over-production, which can lead to plant stress, mainly during the first few years. This problem naturally decreases later with self-shading (VOLTAN et al., 1992).

The intensity of solar radiation over the crop influences the photosynthetic structure. The level of solar radiation can modify the structure of the leaf during its development. Higher solar radiation availability may cause leaf thickness, increases in specific leaf mass by increasing the total cell number (ESAU, 1977). Fahl (1989) verified that sun-grown coffee had thicker leaves and an increased cell density in comparison to shade-grown coffee. This adaptation mechanism has been reported in other plants. In bean plants, for instance, a decrease in specific leaf area (SLA) has been observed with an increase in radiation (RIGHI, 2000).

Voltan et al., (1992) studying the epidermis of coffee grown under different solar radiation availabilities, found that the number of stomata decreased linearly as the solar radiation level decreased, although the stomata size did not change significantly. Alvim (1960), analyzing the photosynthetic rate and stomata conductance in Coffea arabica grown under full-sun and in shade conditions, found that stomata conductance and the photosynthetic net rate were higher in the shade. In Kenya, coffee photosynthesis was higher under lowintensity solar radiation. The total daily assimilation in the shade was higher than in the sun. Coffea canephora generally presents a lower $\mathrm{CO}_{2}$ fixation rate than Coffea arabica, with some genetic variation between cultivars, which can contribute to indicate which genotype is better suited to the Agroforestry System (AFS) (KUMAR and TIESZEN, 1980).

The presence of other trees in the production system alters the radiation balance and also affects air temperature and wind behavior in the area (BRENNER, 1996; MONTEITH et al., 1991; VIEIRA et al., 2003). The multiple effects of these microclimate changes alter the energy balance available to the environment, leading to changes in water use, yield and plant cycle.

The plant canopy structure is related to the spatial distribution of its organs above the soil surface (CAMPBELL and NORMAN, 1989). Plant canopy has an important role in growing and productivity. The canopy architecture is also important to define branch and leaf distribution, altering the interception of available radiation and its use. Efficiency of radiation use is affected by the photosynthetic rate per unit leaf area (BERNARDES, 1987). Leaf area index $\left(\mathrm{LAI}-\mathrm{m}^{2} \cdot \mathrm{m}^{-2}\right)$ and its duration, are the most important factors used to define the dry weight and growth of plants (BERNARDES et al., 1996). Russell et al. (1989) addresses in detail the canopy characteristics and its relationship with the environment.

Environmental factors and quantification of plant behavior can be aggregated in mathematic models to improve its practical and scientific use. Mathematic models, as well the previous research planning, are more important to AFS than to monocrop systems. The pure experimental focus in agrosilviculture is extremely expensive due to: (i) tree longevity; (ii) the size of experimental plots and; (iii) high variety of possible distribution of plants over time and space. Therefore, it is necessary to evaluate the previous literature and develop (and improve) mathematic models, to test the hypothesis beforehand (BERNARDES, 1993). While the development of a complete model is the long-term goal, the individual module process, which is temporary, plays an important role not only for understanding AFS, but also for predicting its performance (BERNARDES, 1993). The mathematic model proposed by Goudriaan (1977) adapted by Bernardes et al. (1998) (Equation 1) accounts for solar radiation values, with good precision, for crops in field conditions (RIGHI, 2000), and can be important to help quantify the availability of solar radiation in an AFS. 
$I_{r}=\frac{I o}{2} \operatorname{sen}\left(\operatorname{arctg}\left(\frac{d-\frac{c_{w}{ }^{2}}{d}}{H_{r}}+D\right)+1\right)$

where,

$\mathrm{I}_{\mathrm{r}}=$ daily radiation $\left(\mathrm{MJ} . \mathrm{m}^{-2}\right)$ that reaches the canopy of the intercalary crop;

$\mathrm{d}=$ distance from the row of shading trees (m);

$\mathrm{I}_{0}=$ daily radiation $\left(\mathrm{MJ} . \mathrm{m}^{-2}\right)$ on a horizontal surface above the tree canopy;

$\mathrm{c}_{\mathrm{w}}=$ tree canopy radius $(\mathrm{m})$;

$\mathrm{D}=$ ground declivity (radians);

$\mathrm{H}_{\mathrm{r}}=$ relative tree height $(\mathrm{m})$, obtained through the equation (2)

$$
H_{r}=H_{a}-H_{c i}
$$

where,

$$
\begin{aligned}
& \mathrm{H}_{\mathrm{a}}=\text { tree height }(\mathrm{m}) ; \\
& \mathrm{H}_{\mathrm{ci}}=\text { height of intercalary crop }(\mathrm{m}) .
\end{aligned}
$$

A better understanding of the ecophysiologic interactions in AFS, raises new scientific questions other than the improvements in crop management. The technological improvement results in better yield, leading to the adoption of AFS by a larger number of rural producers (BERNARDES, 1993). Understanding how the AFS captures and uses the available resources is essential to determine species combination, plant distribution, density and the management best suited for different locations and seasons. Studying resource capture, i.e., solar radiation in an AFS is of great use for the analysis of crop performance under several climate and management conditions (ONG et al., 1996; 1991; WILLEY and REDDY, 1981).

When there is an increase in the amount of available radiation, there is also an increase in the performance of several crops, leading to a higher production of dry matter, in linear correlation with the intercepted radiation (OLIVEIRA et al., 2006; RIGHI, 2000). Russell et al. (1989), modeling the dry matter production in uniform crops, considered that it was almost in direct proportion to the energy intercepted by the canopy. Watson (1958) had already observed that net assimilation rates decrease almost linearly with the LAI, which explains the proportionality between growth and LAI (RUSSELL et al., 1989). The latter authors consider that the interception of solar radiation by the canopy depends on (i) its structure and (ii) the rate of its dry matter production per intercepted radiation unit. This type of analysis, although very frequent in monocrop studies (PEREIRA, 2002; CONFALONE et al., 1997), is not often reported considering such variables in AFS. Although the physical variables are relatively simple to measure, it is very complex to elucidate how these changes affect the crop in the understory (CORLETT et al., 1987).

Šesták (1981) considered that the relation between dry matter and radiation may change over the plant's life, probably due to ontogenetic changes in the canopy, but also due to drain performance on the photosynthetic rate.

This study aims to evaluate the growth of coffee plants (Coffea arabica L.) in an alley AFS of rubber trees (Hevea brasiliensis Müell. Arg.), under different solar radiation availabilities, and to evaluate the model proposed by Goudriaan (1977) to estimate the radiation available to the understory crop.

\section{MATERIALAND METHODS}

The experiment was conducted in the experimental field of the Department of Crop Science of the Escola Superior de Agricultura "Luiz de Queiroz", University of São Paulo (ESALQ/USP) in Piracicaba-SP (2242'30'S, 4738 '00"' - at an altitude of $554 \mathrm{~m}$ ) during the year 2002. The rubber tree field was planted in 1991 at a spacing of $8 \times 2.5$ meters, with seedlings, in plastic bags, which were grafted with two mature leaves. All the experimental blocks consisted of trees from the same clone-PB-235. Coffee was planted at a spacing of $3.4 \times 0.9 \mathrm{~m}$ during the first half of January 2001, underneath the rubber plantation, in an interface with the trees and in monocrop. The cultivar used was Obatã IAC 1669-20 - Mundo Novo. Nine-month old seedlings derived from direct seeding in plastic bags in a nursery with appropriate screen cover.

The experimental area, approximately $0-1.5 \%$ slope, consisted of structured eutrophic Terra Roxa, with moderate A-horizon and clayey-textured, Kandiudalfic Eutrodox by the American soil classification. Soil fertility and the irrigation system set up in the area prevented limited growth and development of plants other than those deriving from the experimental treatment. When 
growing the coffee plants, soil analysis was performed for necessary amendments.

The experiment was arranged in a complete randomized design with 14 treatments - irradiance levels given by the distance from the edge of the trees - and in monocrops planted within the same spacing, weedfree and with no interference from the rubber trees. The 14 treatments included tree distances measured from the first row of rubber trees interfacing with the coffee plantation (zero distance). Negative distances refer to plants on the inside of the rubber tree plantation and the positive distances refer to the distance towards the monocropped coffee. Thus, the treatments used the distances of $-21.7 ;-18.3 ;-13.7 ;-10.3 ;-5.7 ;-2.3$; $1.5 ; 4.9 ; 8.3 ; 11.7 ; 15.1 ; 18.5$ and $21.9 \mathrm{~m}$ from the edge of the trees and in monocrop (Figure 1). A total of 48 plants per distance were evaluated considering each plant as a repetition. Statistical analyses were performed using the SAEG 7.0 software (SISTEMA... 1997), with means compared at $5 \%$ probability by the Tukey test (for data with normal distribution) and Kruskal-Wallis (lack of normality of data distribution). The first row of rubber trees interfacing the coffee crop represents double rows of trees in an alley cropping agroforestry system.

Drip irrigation was used in the coffee plantation keeping the soil humidity near to its field capacity.
The evapotranspiration was estimated by means of a Class A tank, of the Main Meteorological Station of the Department of Exact Sciences, ESALQ-USP, located next to the experiment. The irrigation depth was calculated according to the method proposed by Villa Nova and Sentelhas (1999).

For dry matter evaluation, three coffee plants, from each of the following positions: $-13.7 ;-5.7 ; 1.5 ; 4.9$; $8.3 ; 15.1 \mathrm{~m}$ and from the monocrop, were harvested and dried in a forced-draught oven at $75^{\circ} \mathrm{C}$.

Each coffee plant had the total leaf area calculated, by counting the number of leaves and multiplying this value by the average leaf area. The leaf area corresponded to $68 \%$ of the rectangle calculated on the basis of its size. Therefore, coffee LAI $\left(\mathrm{m}^{2} \cdot \mathrm{m}^{-2}\right)$ is calculated on the basis of plant canopy projection. Other coffee plants characteristics such as height, trunk diameter at $5 \mathrm{~cm}$ above the ground, trunk height, and canopy diameter were measured directly in the same period. The distance from the highest canopy point to the ground was considered the plant height, while the distance between the lowest branch intersection to the ground corresponds to the trunk height. The specific leaf area $\left(\mathrm{SLA}, \mathrm{m}^{2} \cdot \mathrm{kg}^{-1}\right)$ was obtained by dividing the area of 10 leaves, randomly sampled, with three replicates per row, by the value of their constant weight after being dried at $75^{\circ} \mathrm{C}$ in a forced draught oven.

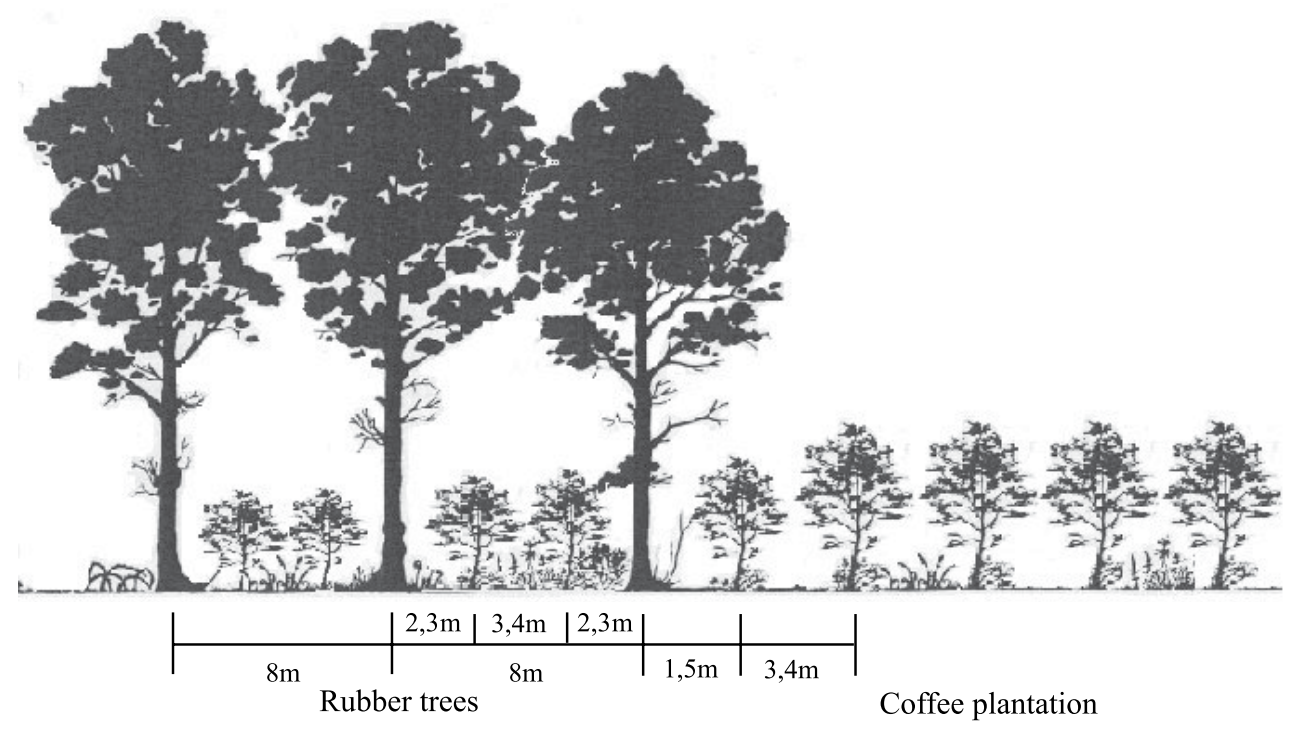

Figure 1 - Cross-section of the experimental field showing the arrangement of rubber trees and coffee plants. Figura 1 - Corte transversal do experimento de campo mostrando a disposição das seringueiras e dos cafeeiros. 
Coffee plants characteristics were evaluated according to the methodology proposed by Leong (1980): (i) trunk diameters at $5 \mathrm{~cm}$ above ground ( $\mathrm{mm})$; (ii) plant height $(\mathrm{cm})$; (iii) trunk height $(\mathrm{cm}) ;($ iv) canopy diameter $(\mathrm{cm}) ;(v)$ canopy height $(\mathrm{cm})$ which is the difference between the measurements of tree and trunk height; ( vi) canopy rounding or canopy filling ratio, which is the average diameters and the canopy length quotient and indicates the circular shape level; (vii) canopy percentage (\%), which is the canopy height divided by plant height multiplied by 100 ; (viii) canopy opening (\%), average canopy diameter divided by plant height multiply by 100 ; ( $i x)$ canopy projection (\%), which is the average canopy diameter divided by the trunk diameter multiply by $100 ;(x)$ canopy volume $\left(\mathrm{cm}^{3}\right)$, which was calculated considering a conic shape, and (xi) leaf density $\left(\mathrm{cm}^{2} . \mathrm{cm}^{-3}\right)$, which is the total leaf area and canopy volume quotient.

The shading trees were measured using a Haga altimeter that measures height through ipsometry, and the canopy diameter was measured with a tape in order to evaluate the radiation available to the intercalary crop as described on equation 1 .

The global solar radiation availability to coffee plants was continuously measured through a tube solarimeter (TS-UM-3, Eijkelkamp), at the same tested positions, and connected to a data-logger (Delta-T Devices). This data was used to evaluate the mathematic model (equation 1).

\section{RESULTS AND DISCUSSION}

Figure 2 shows solar radiation data collected between October and November, 2002. Each point refers to the integral solar radiation available $\left(\mathrm{MJ}^{\mathrm{m}} \mathrm{m}^{-2} \cdot \mathrm{day}^{-1}\right)$. The radiation available to coffee plants under different conditions (distance between the crop and the border trees: (inside) $-13.7 ;-10.3 ;-5.7 ;-2.3 \mathrm{~m}$; (next to the rows) $1.5 ; 4.9 ; 8.3 ; 11.7 ; 15.1 ; 18.5 ; 21.9 \mathrm{~m})$, in percentual terms, it was, respectively, $25 \%$; 30\%; 35\%; 40\%; 45\%; 80\%; $90 \% ; 95 \%$ and approximately $100 \%$ in the three farthest distances.

Figure 3 shows the fraction of radiation available, and the estimate radiation obtained using the mathematical model (Equation 1). Such model can only be used when the tree canopy is not completely closed (GOUDRIAAN, 1977). This way, only the radiation available to coffee plants located beside the rubber trees was simulated.

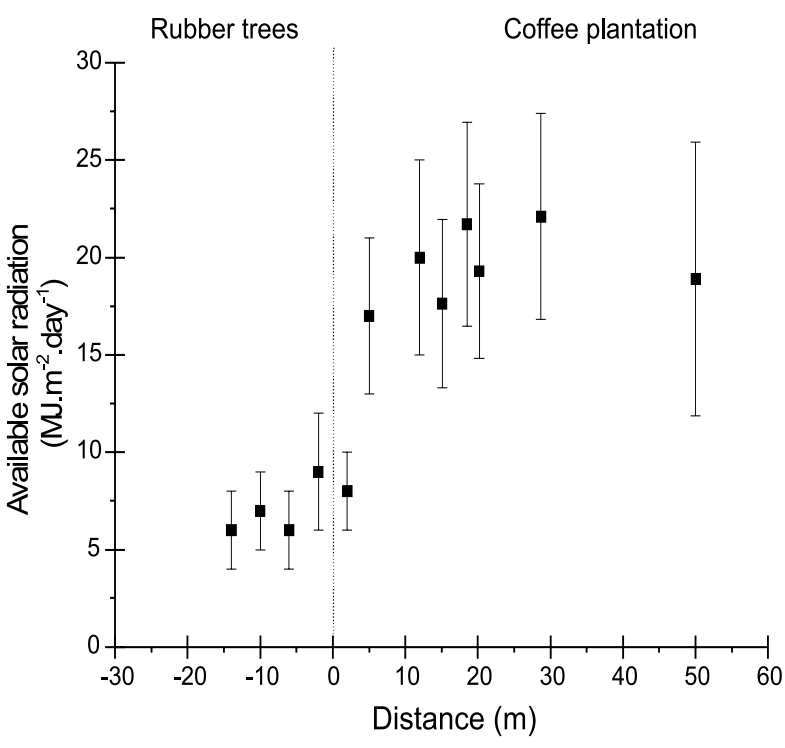

Figure 2 - Solar radiation available $\left(\mathrm{MJ} . \mathrm{m}^{-2}\right.$. day $\left.{ }^{-1}\right)$ to coffee plants measured with a tube solarimeter (TS-UM3, Eijkelkamp) in respect to the distance from the rubber tree plantation and its respective standard deviation. Negative distance refers to the inside of the rubber tree plantation and positive to an increase in distance towards the coffee monocrop. Each point refers to total daily solar radiation during the experimental period and its respective standard deviation.

Figura 2 - Radiação solar disponível (MJ.m ${ }^{-2}$.dia $\left.{ }^{-1}\right)$ aos cafeeiros medida por tubos solarímetros (TS-UM-3, Eijkelkamp), em função da distância da primeira linha de seringueiras. Distâncias negativas referemse ao interior do seringal e positivas, a aumento na distância em direção ao monocultivo de cafeeiro. Cada ponto refere-se à radiação solar total diária durante o período experimental e respectivos desviospadrão.

The radiation available (transmitted fraction) to plants under the closed canopy can be calculated using the Monsi and Saeki (1953) equation, derived from the law of radiation extinction by Beer-Bouguer-Lambert (VIANELLO and ALVES, 2000). This equation can be used to estimate the LAI of plants under different growth conditions as proposed by Villa Nova et al. (2003). The model met the values obtained in several days. These results agree with reports by Bernardes et al. (1998) and Righi (2000), who found measured values close to the estimated values in an alley AFS lined with rubber trees and soybean, and another of rubber trees and beans, respectively. 


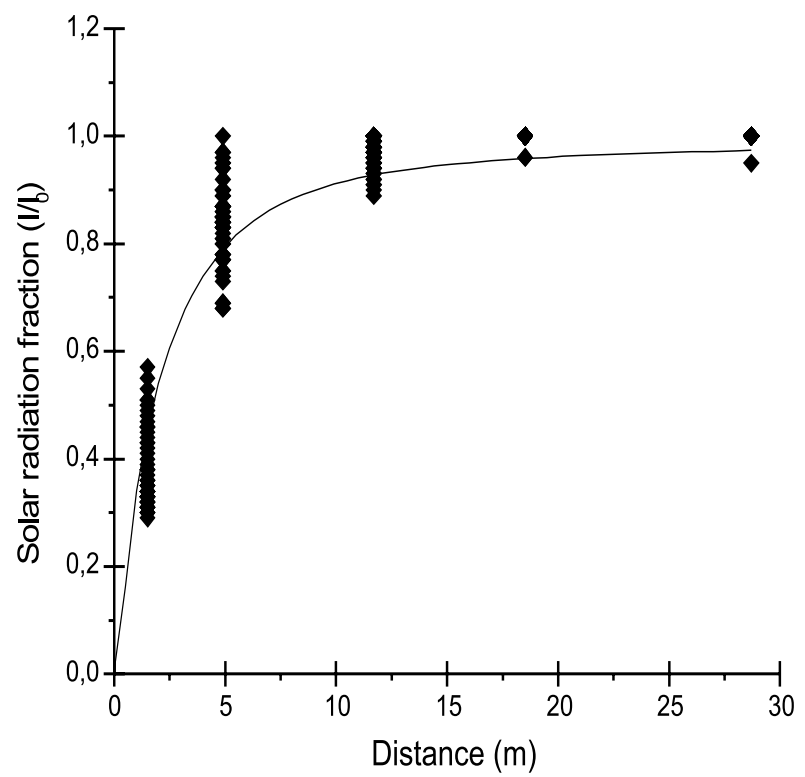

Figure 3-Solar radiation fraction (I/I $\mathrm{I}_{0}$ ) available to coffee plants in respect to the distance from the rubber tree plantation. Line refers to estimated values by the Goudriaan (1977) mathematic model.

Figura 3 - Fração da radiação solar disponível (I/I ${ }_{0}$ ) aos cafeeiros, em função da distância das árvores de seringueira. A linha refere-se a valores estimados pelo modelo matemático de Goudriaan (1977).

Although coffee plants present a clear tendency to show an increase in the specific leaf area (SLA, $\mathrm{m}^{2} \cdot \mathrm{kg}^{-1}$ ) under conditions of shade (Figure 4), it was not enough for equaling the total leaf area (TLA) to those of coffee plants grown under higher solar radiation availability. The higher SLA value obtained $\left(16.69 \mathrm{~m}^{2} \cdot \mathrm{kg}^{-1}\right)$ was approximately $80 \%$ higher than the lowest value obtained (9.17 $\left.\mathrm{m}^{2} \cdot \mathrm{kg}^{-1}\right)$, in which case the plants received the total radiation available (plants in monocrop). Such adaptation has often been observed and reported by several authors (RIGHI, 2000; BERNARDES, 1998; ONG et al., 1996; EVANS et al., 1988; ESAÚ, 1977; PEREIRA, 2002) as one of the main reasons for the success of plants under low light conditions. It was possible to find a greater SLA standard deviation amplitude for the plants located inside the rubber trees plantations (negative distances). This was probably due to the non-uniform natural shade conditions provided by the rubber trees and therefore the existence of many sun-flexes.

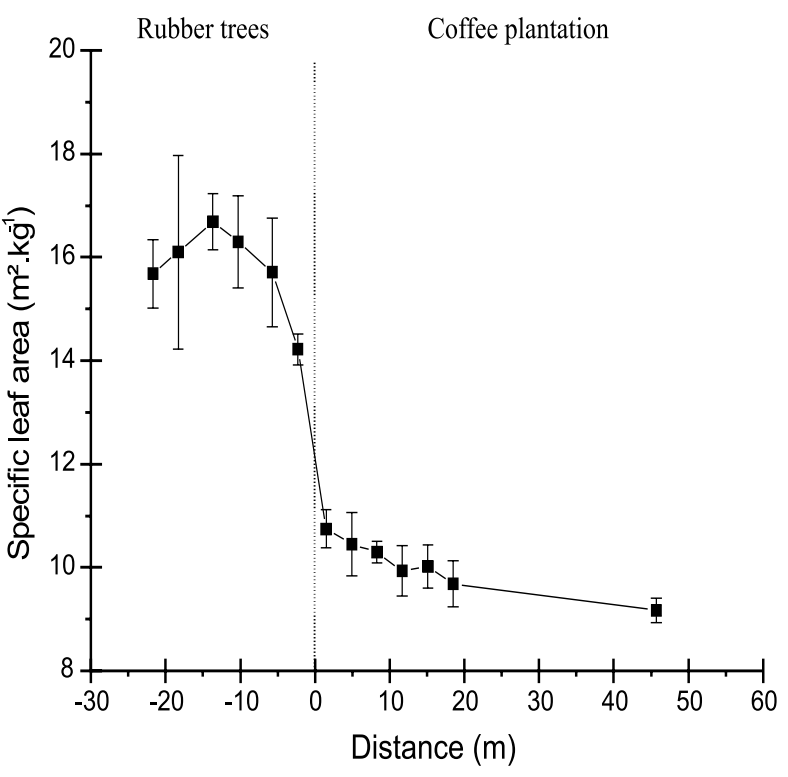

Figure 4 - Specific leaf area $\left(\mathrm{m}^{2} \cdot \mathrm{kg}^{-1}\right)$ of coffee plants in respect to the distance from the rubber tree plantation and its respective standard deviation.

Figura 4-Área foliar específica $\left(\mathrm{m}^{2} . \mathrm{kg}^{-1}\right)$ do cafeeiro, em função da distância das árvores de seringueira e respectivos desvios-padrão.

It is worth pointing out that, despite the extreme difference between the total leaf areas obtained (from $5,370.60$ to $22,617.87 \mathrm{~cm}^{2}$ - about four times larger) (Figure 5a), LAI was similar in each of the plant locations for those placed underneath the rubber tree plantation, and also at 4.9 meters away from the rubber trees, with a solar radiation availability of approximately $80 \%$, towards the monocrop. At the distance of $1.5 \mathrm{~m}$, with radiation close to $45 \%$, the LAI value was intermediate (Table 1). The same variation pattern was found for total leaf area, but with a sudden increase in the first rows next to the rubber trees ( 1.5 and $4.9 \mathrm{~m})$.

Leaf density $\left(\mathrm{cm}^{2}\right.$ leaf. $\mathrm{cm}^{-3}$ canopy) was much higher when coffee plants received close to $100 \%$ solar radiation, double the value in some extreme cases. Higher leaf density (Table 1) and number of leaves (Figure 5b) in illuminated plants confirm the short distance between leaves within the canopy, as well as the barrier against high incidence of radiation. On the other hand, coffee plants under denser shade (under rubber trees, receiving only about $25 \%$ of the total radiation) presented larger leaves, spaced further apart. Among the plants positioned in order to receive more radiation, the average 
leaf area was approximately $45 \mathrm{~cm}^{2}$, while those placed under lower solar radiation availability presented an average leaf area of $55 \mathrm{~cm}^{2}$. The SLA increase in the latter was not enough to equal neither the leaf area nor the LAI to values of plants receiving more solar radiation, resulting in poor soil coverage and interception of radiation. Such decrease leads to smaller growth and dry matter accumulation. When leaf density area is low, there is a high probability that a ray of solar radiation might cross the canopy without being intercepted. On the other hand, under higher leaf density conditions, the solar radiation might be absorbed or dispersed, not reaching the lower canopy layers (RUSSELL et al., 1989). Robledo (1979) found that coffee plants growing under full-sun form an external layer of leaves that absorbs around $90 \%$ of the radiation, resulting in a smaller percentage being available to the inner layers (close to 5\%). Sakamoto and Shaw (1967) observed the same in soybean canopies and Alvim (1977) in cocoa trees. Kumar (1978) reached similar conclusions studying coffee plants in high-density situations (over 15000 plants.ha-1).

Other evaluated parameters share the same tendency observed for LAI (Table 1), with a sharp increase when coffee plants received $45 \%$ of the available radiance, which occurred at the first position, when coffee plants were $1.5 \mathrm{~m}$ away from the trees. It is possible to observe the existence of two landing values with a transition zone ( $45 \%$ solar radiation availability) that suggests coffee plants are very sensitive to further solar radiation decrease, which can be considered a turning point. Horn (1971) had already observed that there is an increase in carbon fixation if the canopy layer increases (LAI). Increases in radiation levels lead to an improvement in solar radiation transmission, which results in a larger LAI. Thus, plants exposed to the sun present leaves in a diffused arrangement, in several layers; while plants under shade conditions present leaves in a uniform layer (HORN, 1971). Low self-shading strongly affects the carbon balance, mainly in environments where radiation is close to the compensation point (GIVINISH, 1984).

LAI was slightly smaller in denser shaded places, since its calculation considered the canopy projection. It was clear that there was no increase in the area covertures, given by the canopy diameter, with the increase in irradiance and vice versa. Larger canopy diameters $(81.48$ and $81.81 \mathrm{~cm})$ were found closer to the rubber trees - at the distances of -2.3 and $1.5 \mathrm{~m}$.
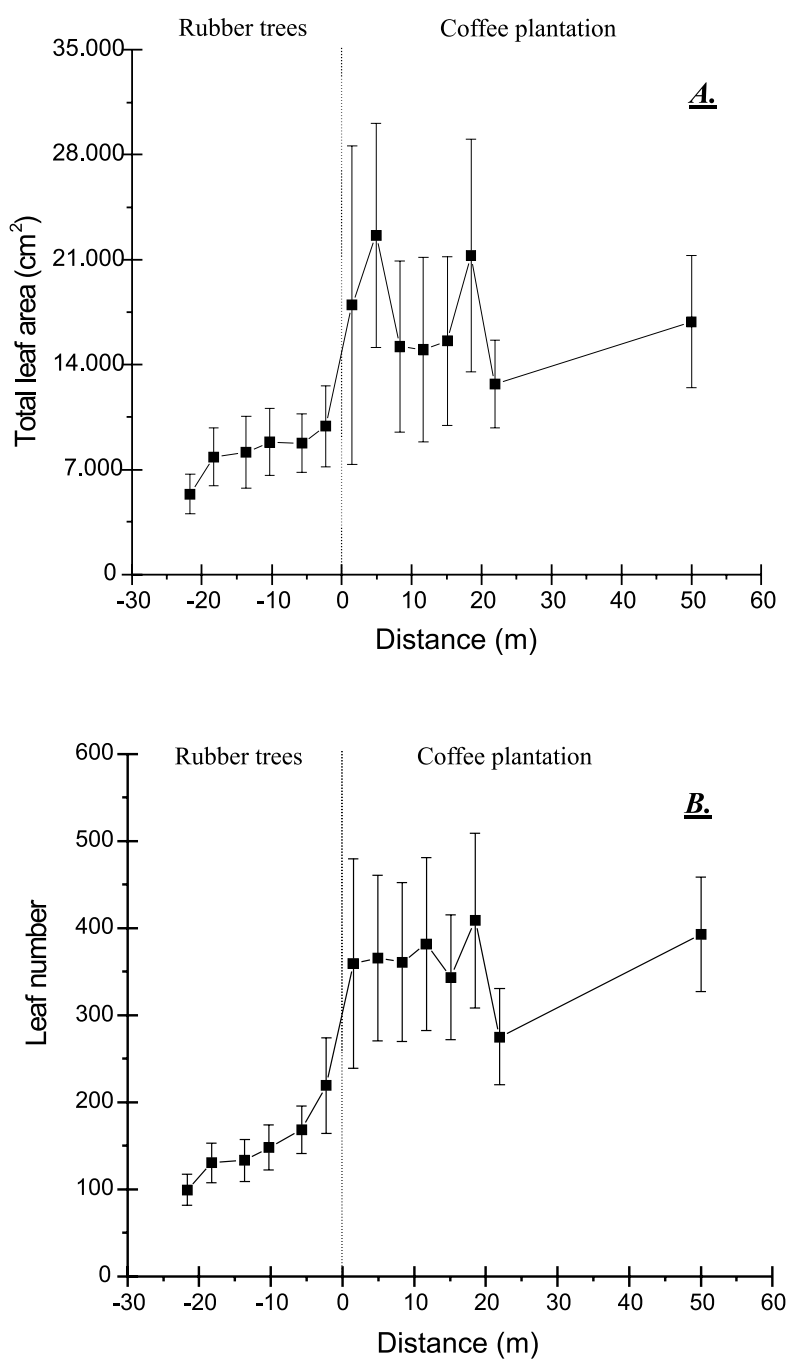

Figure 5-(a) Total leaf area $\left(\mathrm{cm}^{2}\right)$ of coffee plants in respect to the distance from the rubber tree plantation and its respective standard deviation; (b) Average number of leaves of coffee plants in relation to the distance from the rubber tree plantation and its respective standard deviation.

Figura 5-(a) Área foliar total $\left(\mathrm{cm}^{2}\right)$ dos cafeeiros, em função da distância das árvores de seringueira e respectivos desvios-padrão; (b) Número médio de folhas dos cafeeiros, em função da distância das árvores de seringueira e respectivos desvios-padrão.

The canopy opening did not change much in the evaluated positions, suggesting that it is a conservative parameter, despite tendencies to increase under shade (maximum values of 130 under shade against 115 under sun) (Table 1). Canopy opening was close to the estimates 
by King (1981) and recorded by Givinish (1986). In spite of a decrease in radiance availability to the coffee plants near the edge of the trees, and the fact that there was still enough space between rows, which would allow for bigger canopy openings, the plants were touching each other in the rows, leading to an increase in height.

The sharp reduction in the canopy projection with the distance from the edge of the trees was mostly due to an increase in trunk diameter (from $11.38 \mathrm{~mm}$ in denser shaded areas to $19.47 \mathrm{~mm}$ ) than to differences in canopy diameters (Table 1).

Coffee plants showed a clear variation in canopy architecture, mainly vertically, as observed in the canopy height, which increased closer to the rubber trees edge. The canopy percentage suggests a higher capacity of plants to intercept and use radiance. The same pattern was found for canopy volume, despite a strong inflexion in intermediate distances. The largest canopy volume was recorded at $1.5 \mathrm{~m}\left(92,284.26 \mathrm{~cm}^{3}\right)$. Such results indicate a canopy architecture plasticity of coffee plants under different solar radiation availabilities, with several interception and use patterns.

Because of vertical growth due to neighboring plants and solar radiation availability decrease caused by the rubber trees, the lowest branch intersection (given by the trunk height) was higher in shaded plants $(24.5 \mathrm{~cm})$. There was a tendency to decrease towards a monocrop (where lowest trunk intersection was about $19 \mathrm{~cm})$. Higher trunk height contributes to improve canopy opening and leads to an oblong shape (2.5) of the coffee canopies under shade, while those under full sun (monocrop) presented a tendency towards spherical canopies (1.5) (Table 1).

Loss of basal branches in coffee plants is very often related to planting in high density or under overshaded conditions. Coffee plants do not replace plagiotropic branches (yield branches), even when there is an increase in irradiance, deeming the plant permanently damaged and consequent substantial yield loss.

Monsi and Saeki (1953) demonstrated that the extinction coefficient $(\mathrm{k})$ tends to be higher in species with wider and horizontally distributed leaves $(k \approx 0.6$ to 0.9$)$ than in those with smaller and vertical leaves $\mathrm{s}(\mathrm{k} \approx 0.3$ to 0.5$)$. It is expected that under shade conditions the solar radiation extinction coefficient would be higher than those found in solar radiation conditions, but such fact needs further studies. Robledo (1979) observed $\mathrm{k}$ values of around $0.41 \pm 0.15$ inside the coffee canopy, with radiation extinction occurring in an exponential way at noon, when coffee plants presented lower albedo. These facts indicate that coffee is highly efficient on energy absorption.

Coffee plants present several characteristics that allow a strong attenuation of the available radiation. Cannel (1976) found that coffee plants use a large part of their dry matter to increase the leaf area. Coffee plants show high solar radiation transmission inside the canopy, upper branches in small angles, leaves placed in long vertical distances and conical shape that prevent self shading.

Besides LAI, another important geometric canopy characteristic that determines the net carbon assimilation is its mechanic efficiency, the energy fraction allocated to the leaves in relation to non-productive organs. Canopies are important for harvest and energy conversion, and also for competition (GIVINISH, 1988). This author consider that leaf maintenance cost has to include the compensation point, as well as leaf, branches and roots construction, that increase the ecological compensation point. In this manner, the maintenance cost and the plant height are important to determine its survival under shade condition. Givinish (1988) reanalyzed Björkman et al. (1972) data and suggested to express photosynthesis and respiration as a function of leaf mass or protein content in a way to incorporate the leaf construction costs and to asses its adaptation to solar radiation level, which becomes more apparent than if expressed by leaf area. By doing this, the higher rates of return at low irradiances of leaves adapted to those conditions become evident. This way, it would be not a surprise that canopies under direct sun, with leaves exposed to many different solar radiation environments and adapted to them, have each individual leaf working at its maximum. Thus, even with a photosynthetic tissue larger than those present on shaded plants, the sun plants - as in this case with double LAI - presented about the same total dry matter accumulation. 


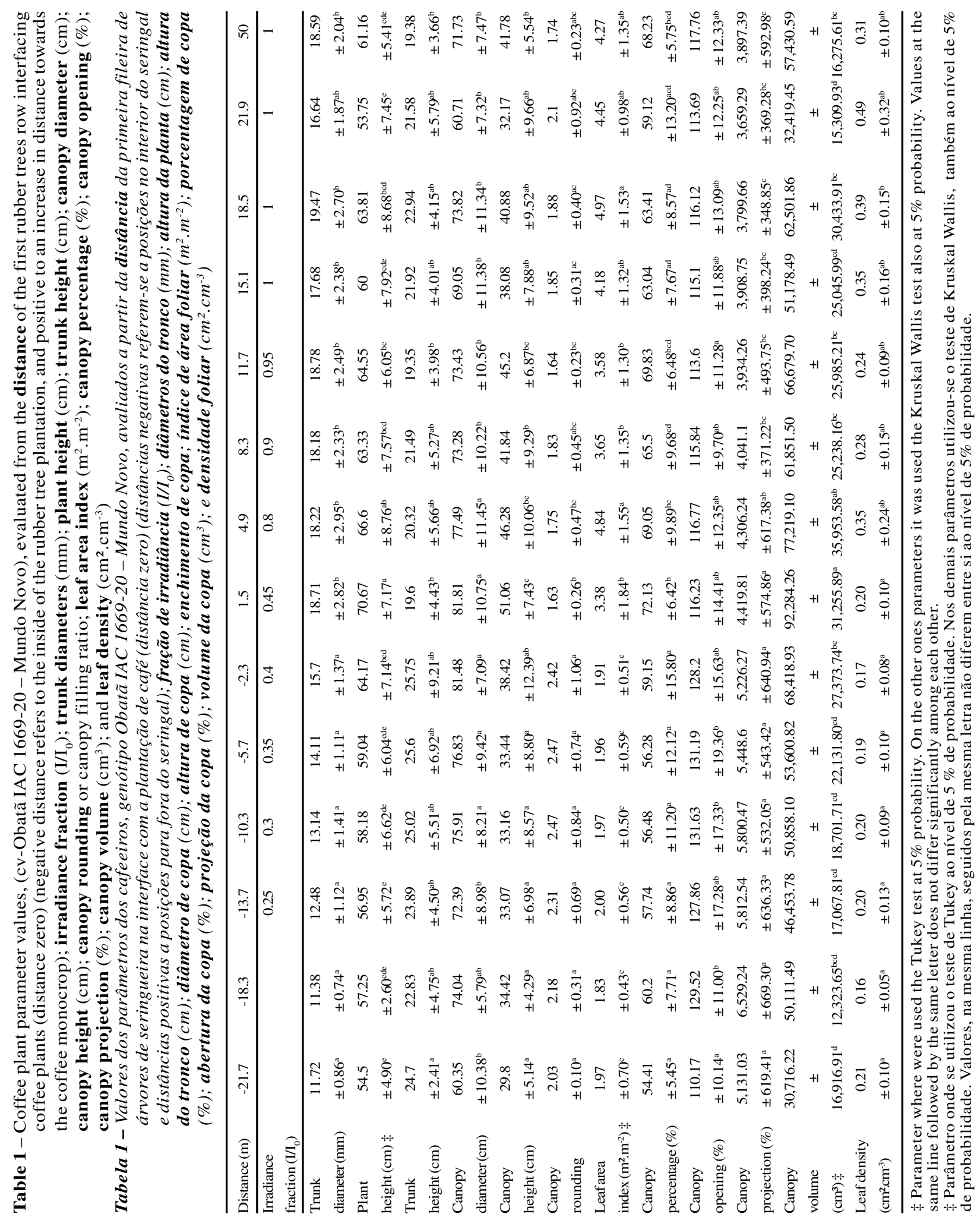


Figures $6 a$ e $6 b$ shows the total dry matter produced versus the available solar radiation. A good development can be observed under $45 \%$ of the total solar radiation available, at $1.5 \mathrm{~m}$ from the rubber trees. The results obtained differ from those widely reported in respect to their direct correlation (PEREIRA, 2002; RIGHI, 2000; CONFALONE et al., 1997; RUSSELLet al., 1989). Such fact is probably due to previous studies being carried out with plants that had fast growth and canopy closure, whereas, on this study, the canopy closure was partial. Thus, the available radiation interception was very different at the evaluated positions, and no good correlation was found. Another alternative explanation to the abrupt decrease in dry matter accumulation, and its relation with the available radiance to coffee plants at $-5.7 \mathrm{~m}$ from the trees (around $35 \%$ of radiation), may be the active photosynthetic radiation (PAR), as these coffee plants were completely underneath the rubber trees, which act as a radiance filter (RUSSELL et al., 1989; LARCHER, 1975). Nevertheless, more than such decrease, it is important to emphasize the likely increase in radiance interception efficiency and its conversion by plants at $1.5 \mathrm{~m}$ from trees (with $45 \%$ of the irradiance). Yet, in the Figure $6 a$ we can observe that all the coffee plants located under less than $45 \%$ solar radiation presented a dry matter fraction above the line $1: 1$, indicating a radiation use efficiency better than the coffee plants located under sunnier positions.

Russell et al. (1989) consider that the linear growth response to absorbed PAR was expected, since the canopy was not exposed to saturating radiances during most of its growth season. The point is, did plants, at $1.5 \mathrm{~m}$ from the trees, reach the saturation of their canopy with only $45 \%$ of the available radiation? Such radiation values would be close to the saturation point of isolated leaves (close to $1 / 3$ of the irradiance in a clear summer day), far from those that normally would saturate a canopy. In the case of this hypothesis being right, if data were not considered, the correlation would be much higher and a better adjustment would change $\mathrm{r}^{2}$ from 0.44 to 0.78 .

The Gompertz model gave a good fit to the collected data, with $\mathrm{r}^{2}=0.77$ (Figure $6 b$ ). This model clearly showed that coffee plants reach the saturation point at $45 \%$ of the available irradiance. It is possible to observe a linear correlation until reaching the saturation point as Russell et al. (1989) demonstrated. At $45 \%$ of the radiation, dry matter values were at the same landing of the plants under full sun (monocrop).
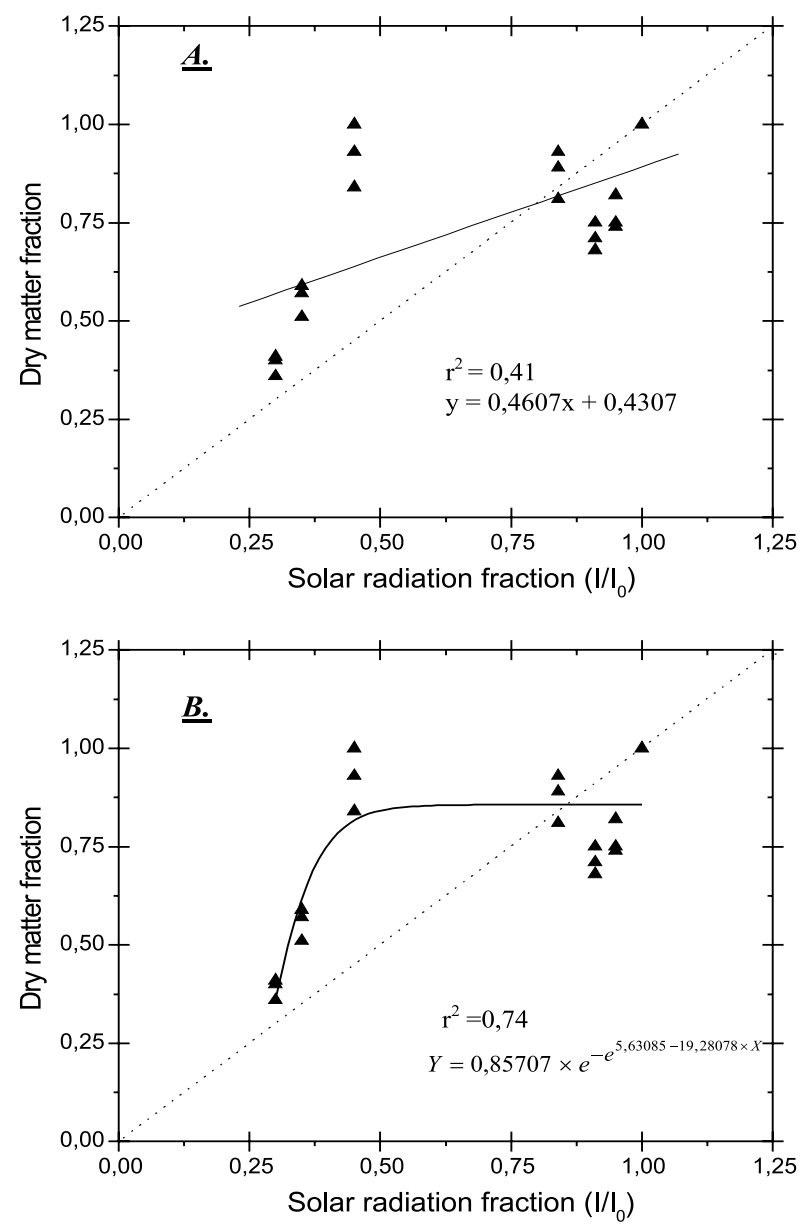

Figure 6-(a) Above ground dry matter fraction as a function of available radiation fraction $(\mathrm{I} / \mathrm{I})$ e; (b) Adjustment of the Gompertz model to the dry matter fraction of the coffee plants as a function of the available radiation fraction $\left(\mathrm{I} / \mathrm{I}_{0}\right)$.

Figure 6- (a) Fração de matéria seca acima do solo, em função da fração de radiação disponível ( $\left(/ I_{0}\right)$; $e$ (b) Ajuste do modelo de Gompertz à fração de matéria seca do cafeeiro, em função da fração de radiação disponível $\left(I / I_{0}\right)$.

\section{CONCLUSION}

The mathematic model, proposed by Goudriaan (1977) adapted by Bernardes et al. (1998), properly describes the solar radiation available to intercalary plants. It can be an important tool to AFS planning and analysis.

Coffee plants presented good plasticity with changes in SLA, LAI, leaf density, canopy geometry and radiation 
interception and use.

The crop did not present a good linear correlation between available radiance and dry matter accumulation, probably due to canopy saturation at $45 \%$ of the available radiation. The best adjustment was obtained with the Gompertz model.

No decrease in dry matter accumulation was observed when the irradiance was at $45 \%$ of availability. Further reductions on solar radiation availability caused abrupt decreases in dry matter accumulation, and changes in the adaptation to such conditions.

Due to its high capacity for adaptation to significant decreases in solar radiation availability, coffee cultivation in AFS has good prospects.

\section{FINAL CONSIDERATIONS}

There still is a large the number of papers on solar radiation influence without any reference to its measurement, limiting themselves to determine whether the treatment was shaded or not. The authors would like to stress the importance of solar radiation measurement, since it is the main energy source driving all the processes and has a number of implications over the production system.

The use of AFS by coffee producers can result in the development of this crop in regions previously declared improper due mainly to stress caused by inappropriate temperatures. As studies of irradiance carry an inevitable thermal component (infra red thermal), it is common sense among researchers that coffee plants do not tolerate high radiation levels. This is not true, as we can see from many coffee plantations near the equatorial zone, e.g. in Brazil and Kenya, as far as air temperature allows it. Future works on the play and exchange processes of temperature seem to be very promising for the future development of AFS and coffee crop.

There is a lack of studies on Coffea canephora in AFS that could be considered for tropical agriculture under high air temperature.

\section{ACKNOWLEDGEMENTS}

Special thanks to the State Agency for Research of São Paulo/Brazil - FAPESP - for the support and to Prof. Dr. José Dias Costa for his unconditional help and ideas.

\section{REFERENCES}

ALVIM, P.T. Physiology of growth and flowering in coffee. Turrialba, v.2, p.57-62, 1960.

ALVIM, P.T. Cacau. In: ALVIM, P.T.; KOZLOWSKI, T.T. (Ed.), Ecophysiology of tropical crops. New York: Academy Press, 1977. p.279-313.

BERNARDES, M.S. Fotossíntese no dossel das plantas cultivadas. In: CASTRO, P.R.C.; FERREIRA, S.O.; YAMADA, T. (Ed.), Ecofisiologia da produção agrícola. Piracicaba: PATAFOS, 1987. p.13-48.

BERNARDES, M.S. Simulation of agroforestry systems: the case of rubber tree associated with other crops. Wageningen: Wageningen Agricultural University, 1993. 63p. (Doctor Degree Program).

BERNARDES, M.S. et al. Tree-crop interactions in agroforestry system of rubber with soybean and maize. In: CONGRESS OF THE EUROPEAN SOCIETY FOR AGRONOMY, 5., 1998, Nitra. Slovakia. Short communications. Slovakia: ESA, 1998. v.2, p.125-126.

BERNARDES, M.S. et al. Interações abaixo da superfície do solo em sistema agroflorestal de seringueira (Hevea brasiliensis) e milho (Zea mays). In: CONGRESSO BRASILEIRO EM SISTEMAS AGROFLORESTAIS, 2., Belém. Resumos expandidos. Belém: CPATU, 1998. p.14-16.

BERNARDES, M.S.; CASTRO, P.R.C.; MARTINS, A.N. Formação da copa e resistência de árvores ao vento: modelo de seringueira. Piracicaba: FEALQ, 1996. 88 p.

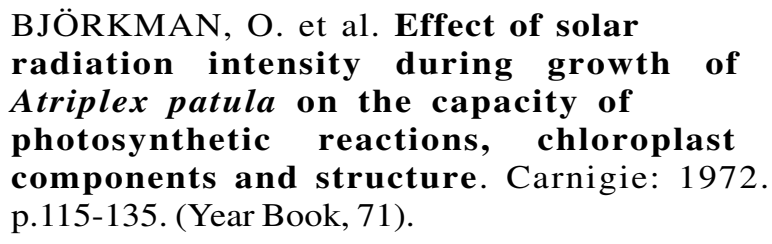

BRENNER, A.J. Microclimatic modifications in agroforestry. In: ONG C. K.; HUXLEY, P. (Ed.), Tree-crop interactions, a physiological approach. Wallingford: CAB International, 1996. p.159-188.

R. Árvore, Viçosa-MG, v.31, n.2, p.195-207, 2007 
CAMPBELL, G.S.; NORMAN, J.M. The description and measurement of plant canopy structure. In: RUSSEL, G.; MARSHALL, B.; JARVIS, P.G. (Ed.), Plant canpies: their growth, form and function. Cambridge: Cambridge University Press, 1989. p.1-20.

CANNEL, M.G.R. Crop physiological aspects of coffee bean yield. Kenya Coffee, v.41, n.484, p.245-253, 1976.

CONFALONE, A.E.; COSTA, L.C.; PEREIRA, C.R. Eficiencia de uso de la radiación en distintas fases fenológicas bajo estrés hídrico. Revista de la Facultad de Agronomía. v. 17, n.1, p.63-66, 1997.

CORLETT, J.E.; ONG, C.K.; BLACK, C.R. Microclimatic modifications in intercropping and alley cropping systems. In REIFSNYDER, W.S.; DARNHOFER, T.O. (Ed.),

Meteorology and agroforestry. Nairobi: ICRAF, 1987. p.419-430.

ESAU, K. Anatomy of seed plants. New York: John Wiley, 1977. 550p.

EVANOFF, C.E.A. Biologia del cafe. Caracas: Universidade Central de Venezuela, 1994. 308 p. (Colección Estudios).

EVANS, J.R.; CAEMMERER, S.V.; ADAMS III, W.W. Ecology of photosynthesis in sun and shade. Melbourne: CSIRO, 1988. 358p.

FAHL, J.J. Influência da irradiância e do nitrogênio na fotossíntese e crescimento de plantas jovens de café (Coffea arabica L.). 1989. 84f. Tese (Doutorado em Biologia Vegetal) - Universidade de Campinas, Campinas, 1989.

GIVINISH, T.J. Adaptation to sun and shade: a whole-plant perspective. In: EVANS, J.R.,

CAEMMERER, S. VON; ADAMS III, W.W. (Ed.),

Ecology of photosynthesis in sun and shade. Melbourne: CSIRO, 1988. p.63-92.

GIVINISH, T.J. On the economy of plant form and function. Cambridge: Cambridge University Press, 1986. 680p.

R. Árvore, Viçosa-MG, v.31, n.2, p.195-207, 2007
GIVINISH, T.J. Leaf and canopy adaptations in tropical forests. in: MEDINA, E.; MOONEY, H.A.; VÁSQUEZ-YÁNES, C. (Ed.), Physiological ecology of plants of the wet tropics. The Hague: Dr. Junk, 1984. p.51-84.

GOUDRIAAN, J. Crop micrometeorology: a simulation study. Wageningen: PUDOC, 1977. 249p. (Simulation Monographs).

HORN, H.S. The adaptive geometry of trees. Princeton: Princeton University Press, 1971. 251p.

KING, D. Tree dimensions: maximizing the rate of height growth in dense stands. Oecologia, v.51, p.351-356, 1981 .

KRUG, C.A. World coffee survey. Roma: FAO, 1959. 292p.

KUMAR D.; TIESZEN, L.L. Photosynthesis in Coffea arabica L. II. Effect of water stress. Experimental Agriculture. v.16, p.21-27, 1980.

KUMAR, D. Some aspects of the physiology of Coffea arabica L. A review. Coffee Kenya. v.44, p.9-47, 1979.

KUMAR, D. Investigation into some physiological aspects of high density plantings of coffee (Coffea arabica L.). Coffee Kenya, v.43, p.263-272, 1978.

LARCHER, W. Physiological plant ecology. Berlin: Springer-Verlag, 1995. 252p.

LEONG, W. Canopy modification and its effects on growth and yield of Hevea brasiliensis. 1980. 283f. Thesis (Ph.D. in Ecology) Faculty of Agricultural Sciences of Ghent, Belgium, 1980.

MONSI, M.; SAEKI, T. Über den lichtfaktor in den planzen-gesell-schaften und seine bedeutung für die Stoffproduktion. Japon Jardin Botanique, v.14, p.22-52, 1953.

MONTEITH, J.L.; ONG, C.K.; CORLETT, J.E. Microclimatic interactions by in agroforestry systems. Forest Ecology and Management, v.45, p.31-44, 1991. 
OLIVEIRA, C.R.M. et al. Trocas gasosas de cafeeiros (coffea arabica 1.) e seringueiras (Hevea brasiliensis Muell. Arg.) em diferentes sistemas de cultivo na região de Lavras, MG. Revista Árvore, v.30, n.2, p.197-206, 2006.

ONG, C.K. et al. Principles of resource capture and utilization of solar radiation and water. In: ONG, C. K.; HUXLEY, P. (Ed.), Tree-crop interactions: A physiological approach. Wallingford: CAB International, 1996. p.73-158.

ONG, C.K. et al. Above and below-ground interactions in agroforestry systems. Forest Ecology and Management, v.45, p.45-57, 1991.

PEREIRA, C. R. Análise do crescimento e desenvolvimento da cultura da soja sob diferentes condições ambientais. 2002. 282f. Tese (Doutorado em Agronomia) Universidade Federal de Viçosa, Viçosa, 2002.

RIGHI, C.A. Interações ecofisiológicas acima e abaixo do solo em um sistema agroflorestal de seringueira (Hevea brasiliensis) e feijoeiro (Phaseolus vulgaris). 2000. 130f. Dissertação (Mestrado em Agronomia) - Escola Superior de Agricultura Luiz de Queiroz, Piracicaba, 2000.

ROBLEDO, A.J. Balanço de radiação solar em Coffea arabiica $L$. variedade Catuaí e Bourbon Amarelo. 1979. $68 \mathrm{f}$. Dissertação (Mestrado em Agronomia) - Escola Superior de Agricultura Luiz de Queiroz, Piracicaba, 1979.

RUSSEL, G.; JARVIS, P.G.; MONTEITH, J.L. Absorption of radiation by canopies and stand growth. In: RUSSEL, G.; MARSHALL, B.; JARVIS, P.G. (Ed.), Plant canpies: their growth, form and function. Cambridge: Cambridge University Press, 1989. p.21-40.

\section{SISTEMA PARA ANÁLISES} ESTATÍSTICAS E GENÉTICAS SAEG. Versão 7.0. Viçosa, MG: Universidade Federal de Viçosa, 1997.

SAKAMOTO, C.M.; SHAW, R.S. Solar radiation distribution in field soybeans canopies. Agronomy Journal, v.59, n.1, p.7-9, 1967.
ŠESTÁK, Z. Leaf ontogeny and photosynthesis. In: JOHNSON, C.B. (Ed.), Physiological processes limiting plant productivity. London: Butterworths, 1981.p.147-158.

VIANELLO, R.L.; ALVES, A.R. Meteorologia básica e aplicações. Universidade Federal de Viçosa, 2000. 449p.

VIEIRA, A.R.; FEISTAUER, D.; SILVA, V.P. Adaptação de espécies arbóreas nativas em um sistema agrossilvicultural, submetidas a extremos climáticos de geada na região de Florianópolis. Revista Árvore, v.27, n.5, p.627-634, 2003

VILLA NOVA, N.A.; SENTELHAS, P.C.

Evapotranspiração máxima do feijoeiro, cv. Goiano precoce, em função do índice de área foliar e da evapotranspiração do tanque Classe A. In: REUNIÃO LATINO-AMERICANA DE AGROMETEOROLOGIA, 2., 1999, Florianópolis. Anais... Florianópolis: Sociedade Brasileira de Agrometeorologia. p.212-218

VILLA NOVA, N.A. et al. Determinação da área foliar de árvores adultas de lima ácida 'Tahiti' e do índice de área foliar de um seringal com luxímetro de baixo custo. In: CONIRD - CONGRESSO NACIONAL DE IRRIGAÇÃO DE DRENAGEM - 13., 2003, Juazeiro. Anais... Juazeiro: 2003. V.1.p.32-34.

VOLTAN, R.B.Q.; FAHL, J.J.; CARELLI, M.L.C. Variação na anatomia foliar de cafeeiros submetidos a diferentes intensidades luminosas. Brazilian Journal of Plant Physiology, v.4, n.2, p.99-105, 1992.

WATSON, D.J. The dependence of net assimilation rate on leaf area index. Annals of Botany, v.22, p.37-54, 1958.

WILLEY, R.W.; REDDY, M.S. A field technic for separating above-and bellow interactions in intercropping and experiment with pearl millet groundnut. Experimental Agriculture. v.17, p.257-264, 1981.

R. Árvore, Viçosa-MG, v.31, n.2, p.195-207, 2007 